\title{
SIGNIFICANCE OF EVENTS IN FORMING A COMPETITIVE DESTINATION'S TOURIST PRODUCT: CASE STUDY: VARAŽDIN ŠPANCIRFEST
}

\author{
Danijel Drpić \\ Danijel Vučenović \\ Ivan Čapeta
}

https://doi.org/10.20867/tosee.05.22

\begin{abstract}
Purpose - The purpose of the paper is to explore the possibilities for improvement of the existing tourist offer of Varaždin on the example of Špancirfest as one of the fastest growing tourist events in Croatia through stronger inclusion of the elements of material and non-material heritage.

Methodology - The empirical research was conducted during the Špancirfest in 2016 by using a structured questionnaire. Data analysis was conducted with the use of SPSS 21 statistical package. Mann-Whitney U Test and Pearson Coefficient of Correlation, Kruskal-Wallis Test were used in order to determine the influence of observed parametres of the analysis on the value of the observed categories. Other scientific methods that were used are historical method, method of induction and deduction, method of conclusion, desk-research and others.

Findings - In order to improve the existing offer of Špancirfest, it is necessary to determine the habits, desires and satisfaction of visitors of Špancirfest, and based on them to form a new developmental and marketing strategy of Varaždin and North-West Croatia.

Contribution - Based on studying the relevant scientific literature, secondary statistical indicators and conducted empirical research, the developmental guidelines were created with a goal of further improvement of event intended to all destination stakeholders with a particular accent on the need of stronger inclusion of heritage elements into the current tourist product with a goal of its preservation and strengthening recognizability and uniqueness of event on the tourist market.

Keywords Tourist events, Špancirfest, management, competitiveness
\end{abstract}

\section{INTRODUCTION}

Tourist events based on heritage, especially non-material heritage, represent a key link for the development of a sustainable and recognizable tourist offer that guarantees the preservation of identity of a destination, and generates the strengthening of mutual connection between the visitor and the offer host. Aside from the preservation of identity, a tourist event has a positive impact on the whole sustainable development of a destination as well as the total economical excellence of stakeholders in the destination. Competitive advantage represents a basic goal for all stakeholders within the destination as a competitive unit, which is permanently positioned in relation with the market, by satisfying the needs and wants of potential visitors, the local community, and economical factors in a destination and its surroundings. The before mentioned is possible to achieve by improving the existing tourist offer, especially if it is immersed with the elements of heritage which become factors of an authentic and innovative tourist product. 
ToSEE - Tourism in Southern and Eastern Europe, Vol. 5, pp. 233-247, 2019

D. Drpić, D. Vučenović, I. Čapeta: SIGNIFICANCE OF EVENTS IN FORMING A COMPETITIVE ...

\section{THEORETICAL BACKGROUND}

\subsection{Tourist events as an improvement model of competitive abilities of a destination}

Contemporary tendencies in tourism point to sustainability being the key to success, and it is based on acceptance of tourism by the broader local community that lives on the site of the tourist attraction, as well as the economic and monetary movements in the surroundings conditioned by tourism (Swarbrooke, 1999; Weaver, 2006; Hall, 1997; Getz, 2005, 2008; Gržinić, 2018). Tourist events present an ideal element for including the broader spectrum of single products in a unique product of added value. Scientific literature mostly presents scientific considerations of ecological, sociodemographic, economic, and cultural segments of tourist events (Milohnić \&Trošt, 2011; Tassiopoulos and Johnson, 2009; Henderson, 2011; Drpić, 2017; Gržinić, 2018; Deery and Jago, 2010; McHone and Rungeling, 2000; Wood, 2005; Griffin and Hayllar, 2009), and securing sustainability and longevity of the tourist event (David, 2009; Presbury and Edwards, 2010; Musgrave, 2011). According to the Development strategy of tourism in the Republic of Croatia by year 2020 (Government of the Republic of Croatia, 2013), the Republic of Croatia sees significant potential for improvement of the tourist offer by developing the offer of cultural tourism, as a set of innovative products that will mark Croatia as a new interesting cultural destination full of content. Those recognized cultural destinations should be situated in the continental and gulf coast area of Croatia. Especially important products of cultural tourism in Croatia include: city tourism, heritage tourism, event tourism, creative tourism, and religious tourism. One of the stated priority activities by 2020 is the development of new events with the potential of international recognizability, where surely Špancirfest could be sorted, as one of the most recognized tourist events in Croatia.

Events make a significant source of income for many destinations, securing high employment, visitor satisfaction, and better quality of life for the local community, and others. Events as a complex tourist product have a very high importance in tourism. For some tourists they represent additional facility if their primary motive is arriving to a destination different from what is offered within the event, while for some they represent the reason for coming to a destination as a primary tourist attraction and product (Čorak and Trezner, 2014).

Tourist attractions are the basic developmental resource of every tourist destination, based on which the tourist supply is formed and the tourist development is determined. If tourist attractions are carefully determined and included in the tourist product, they significantly contribute to the realization of competitiveness of a destination on the tourist market. Product competitiveness in tourism can be determined in a way to please the tourist needs, motives and activities on a higher level than competing destinations (Kušen, 2002). The increase in tourist numbers who come to the specific destination because of an event means that the destination is capable of sustaining and increasing the number of activities, by which it generates new demand which increases its competitiveness. 
ToSEE - Tourism in Southern and Eastern Europe, Vol. 5, pp. 233-247, 2019

D. Drpić, D. Vučenović, I. Čapeta: SIGNIFICANCE OF EVENTS IN FORMING A COMPETITIVE ...

Competitiveness of a tourist destination can be determined as a management ability of a tourist destination to be able to advance on all levels as well as optimally combine the executed elements and natural elements of the tourist offer, while the main goal of every destination is to establish a long-term and a sustainable competitive advantage on the tourist market. Competitive advantage of a destination determines the success of management of a tourist product as a core element of its success, in other words, with its adaptability according to the requests of tourist demand, and which must be derived from developmental strategies of a destination accepted by all the destination stakeholders (Magaš et al., 2018; Cooper, 1998; Gračan, Rudančić-Lugarić, 2013). A great number of destinations with quality and thriving tourist offers aspire to become a brand, which enables the strengthening of recognizability of a destination on the market, as well as its competitive position. Due to its characteristics, events affect almost all aspects of human life, be it the social, cultural, economic, ecological or political (Getz, 2008). Well designed events provide global promotion to a destination because they evoke great attention from the media (Čorak and Trezner, 2014). The competitive advantage of a destination is achieved through its pricing and quality levels (Pirjavec \& Kesar, 2002). Certain destinations lower the prices on the brink of profitability, and by doing so they attract potential tourists, while others base their offer on the level of quality, which implements system innovations and enrich the offer, bringing the destination to a qualitatively higher level of tourist satisfaction (Gračan and Rudančić-Lugarić, 2013).

\section{2. Špancirfest in the function of achieving the competitive advantage of the city of Varaždin}

Špancirfest is a street festival which has been held in the city of Varaždin since 1999, and it takes place on multiple stages across the city. Špancirfest is one of Croatia's most successful festivals, which functions under the slogan "The festival of good emotions". Špancirfest has a positive influence on the whole development of the city of Varaždin. The theme of Špancirfest is "španciranje" - meaning a leisurely walk around the city of Varaždin while enjoying the attractions where visitors can participate in thus becoming the main participants of the event (The Official website of Špancirfest, 2015). Špancirfest has been selected as one of the top 20 festivals of art and culture in Europe in 2018, and the list was composed by the leading European tourist agency Flightnetwork, which finds all the best events and attractions around the whole continent (Flightnetwork, 2018). The richness of the program and the adaptability to all groups of visitors represents one of the basic competitive advantages of Špancirfest, as well as a modern approach to the promotional and marketing activities on the Internet and social networks, which had by all means contributed to the recognizability of the event in Croatia and its surroundings.

\section{METHODOLOGY}

Špancirfest represents one of the most famous and most marketed products of the city of Varaždin, along with its well-known Baroque Evenings. In order to successfully determine the competitive position of the product on the market, it is necessary to explore the socio-demographic factors about the visitors of the event, and to determine their level of satisfaction with the event, in order to be able to recommend further improvements of the tourist offer, and to remove potential deficiencies. Considering that in this research a 
ToSEE - Tourism in Southern and Eastern Europe, Vol. 5, pp. 233-247, 2019

D. Drpić, D. Vučenović, I. Čapeta: SIGNIFICANCE OF EVENTS IN FORMING A COMPETITIVE ...

particular accent is given to the guests who stayed in the accommodation units of Varaždin, the authors consulted the scientific literature such as Ivančić (2015) and Drpić (2017) which studies the models of research of visitors of tourist events. Based on the previously conducted researches which define the representative sample ranging $10-15 \%$ for the needs of this paper, a model was taken according to which a sample of $10 \%$ of the guests of all the accommodation units in the destination was explored due to the fact that no statistical data monitoring the tourist turnover achieved from this event is observed. In the year when the research was conducted, Varaždin disposed with the capacity of 668 beds, and in order to satisfy the condition of $10 \%$ of the respondents, it was necessary to gather 67 correctly filled questionnaires. The results presented in this paper are based on a sample of 73 respondents who agreed to participate voluntarily. The targeted group were the visitors of Špancirfest, who visited the event on August 20, 2016. The respondents were not citizens of Varaždin, in order to lower the influence of partiality which can affect the result and the reliability of the research. An empirical study based on the collection of primary data has been conducted on the field by trained interviewers using a questionnaire method where the main instrument of data collection was a structured questionnaire printed on both Croatian and English, and created based on other formerly conducted studies of similar characteristics. Total of 120 questionnaires was given to the interviewers, and the return response was 73 correctly filled questionnaires, respectively $60.83 \%$. The structured questionnaire was created on the basis of analysis of studies from similar research Ontario Ministry of Tourism (2007), Janeczko et. al (2002), Destination British Columbia (2007), Tomljenović and Marušić (2019), Ivančić (2015), Drpić (2017), Getz (2010), University of Liverpool (2008), and Institute of Tourism Zagreb (2008). The stated research has mentioned the evaluation of tourist events with the aspect of visitors' satisfaction, their motives to visit, their way of getting the information about the events, etc. For the purpose of research of visitors of tourist events, marketing, and quality management, which includes: sources of information, motives for travelling, satisfaction, program's quality and services, costs, the optimal form of research is a visitors' questionnaire (Ivančić, 2015; Getz, 2010). The questionnaire was formed in a way to, besides the socio-demographic information about the respondents (age, gender, level of education, residence, ways of getting the information), with the help of the Likert scale to determine the level of satisfaction with certain elements of the offer with grades from 1 (extremely unsatisfied) to 5 (extremely satisfied).

For the purpose of the research, the following hypothesis were formed:

H1: There are significant differences within the certain socio-demographic indicators of visitors of Špancirfest which affect the level of satisfaction in some elements of the offer.

H2: The largest number of visitors get information about the event via Internet

H3: The satisfaction with the programs and the offer of the tourist event Špancirfest is high. 
ToSEE - Tourism in Southern and Eastern Europe, Vol. 5, pp. 233-247, 2019

D. Drpić, D. Vučenović, I. Čapeta: SIGNIFICANCE OF EVENTS IN FORMING A COMPETITIVE ...

The data was processed using the SPSS 2.0 program with the application of descriptive statistics and measures of dispersion as well as an application of statistical tests: Kruskal Wallis Test and Mann Whitney U test which was conducted with the goal of cognition of influence of the observed analysis parameters on the value of the observed categories. The Mann-Whitney U test falls into the category of non-parametric tests for two variables (non-parametric t-test), while the Kruskal Wallis test belongs to the category of nonparametric tests for groups of more than two variables, a sort of a non-parametric version of the ANOVA test. In the following chapter the authors will present the results of the empirical research conducted during the Špancirfest.

\section{RESULTS}

73 visitors of the event participated in the research, of which $39,7 \%$ were male, and $60,3 \%$ female. The average age of visitors is 38,59, youngest being 16, and the oldest 60 years old. According to the level of formal education, $45,2 \%$ of the respondents had a high-school diploma, $47.9 \%$ had a master's degree, and $6,8 \%$ had a $\mathrm{PhD}$ degree. According to the country of residence, the majority of respondents come from Croatia $39,7 \%$, followed by Slovenia $(28,8 \%)$, and Germany $17,8 \%$. The largest number of respondents visited Špancirfest once $(54,8 \%)$. The largest number of respondents $(42,5 \%)$ prefer to stay in a hotel, $32,9 \%$ in a private accommodation while $24,7 \%$ choose to stay with friends and acquaintances. The largest number of participants visited Špancirfest in a personal arrangement $(86,3 \%)$, and the duration of their stay amounted 1 to 4 days. As the main motive for visiting Varaždin the respondents choose entertainment $(47,9 \%)$, while a primary motive for visiting Špancirfest is a recommendation $(37,0 \%)$, and the image of the tourist event $(27,4 \%)$. It is visible that there are significant differences in certain socio-demographic factors that influence the choice of destination, and the motive to visit an event, considering age, gender, the level of education, and the motive for coming to a tourist event.

Table 1: The satisfaction of Špancirfest visitor in consideration with their gender*

\begin{tabular}{|l|r|r|r|r|}
\hline & $\begin{array}{c}\text { Recognizability } \\
\text { and quality of } \\
\text { facilities and } \\
\text { information }\end{array}$ & $\begin{array}{c}\text { Infrastructural } \\
\text { facilities }\end{array}$ & $\begin{array}{c}\text { Staff service, } \\
\text { prices and } \\
\text { quality of } \\
\text { additional } \\
\text { facilities }\end{array}$ & $\begin{array}{c}\text { General level of } \\
\text { satisfaction } \\
\text { with the visit }\end{array}$ \\
\hline Mann-Whitney U & 607,000 & 633,000 & 396,500 & 547,500 \\
\hline Wilcoxon W & 1597,000 & 1623,000 & 831,500 & 982,500 \\
\hline Z &,- 353 &,- 057 & $-2,755$ & $-1,204$ \\
\hline Asymp. Sig. (2-sided) &, 724 &, 954 &, 006 &, 229 \\
\hline
\end{tabular}

a. Grouping Variable: Gender

Source: Author's analysis

When observing the value of significance for staff service, prices, and quality of additional facilities, it can be seen that the significance of the test amounts to less than $5 \%$, that is $\mathrm{p}=0,006$, so it can be stated that, with the level of reliability of $95 \%$, there is a significant statistical difference between the staff service, prices and quality of additional facilities considering the gender of the respondents, which confirms H1. 
ToSEE - Tourism in Southern and Eastern Europe, Vol. 5, pp. 233-247, 2019 D. Drpić, D. Vučenović, I. Čapeta: SIGNIFICANCE OF EVENTS IN FORMING A COMPETITIVE ...

Table 2: The satisfaction of the respondents considering the age $\mathrm{a}^{\text {a,b }}$

\begin{tabular}{|c|c|c|c|c|}
\hline & $\begin{array}{c}\text { Recognizability } \\
\text { and quality of } \\
\text { facilities and } \\
\text { information }\end{array}$ & $\begin{array}{c}\text { Infrastructural } \\
\text { facilities } \\
\text { prices and quality } \\
\text { of additional } \\
\text { facilities }\end{array}$ & $\begin{array}{c}\text { General level of } \\
\text { satisfaction with } \\
\text { the visit }\end{array}$ \\
\hline Chi-Square & 2,844 & 6,749 & 5,144 & 1,563 \\
\hline df & 2 & 2 & 2 & 2 \\
\hline Asymp. Sig. &, 241 &, 034 &, 076 &, 458 \\
\hline
\end{tabular}

a. Kruskal Wallis Test

b. Grouping Variable: Age category

Source: Author's analysis

If the value of significance for the infrastructural facilities is considered, it can be concluded that the significance of the test amounts to less than $5 \%$, that is $p=0,034$, so it can be stated that, with the level of reliability of $95 \%$, there is a significant statistical difference for the level of satisfaction of the respondents with the infrastructural facilities considering the respondent's age, which confirms H1.

Table 3: The level of satisfaction of the respondents considering their level of education ${ }^{a, b}$

\begin{tabular}{|l|r|r|r|r|}
\hline & $\begin{array}{c}\text { Recognizability } \\
\text { and quality of } \\
\text { facilities and } \\
\text { information }\end{array}$ & $\begin{array}{l}\text { Infrastructural } \\
\text { facilities }\end{array}$ & $\begin{array}{l}\text { Staff service, } \\
\text { prices and quality } \\
\text { of additional } \\
\text { facilities }\end{array}$ & $\begin{array}{l}\text { General level of } \\
\text { satisfaction with } \\
\text { the visit }\end{array}$ \\
\hline Chi-Square & 10,546 & 2,186 & 2,951 & 1,543 \\
\hline df & 2 & 2 & 2 & 2 \\
\hline Asymp. Sig. &, 005 &, 335 &, 229 &, 462 \\
\hline
\end{tabular}

a. Kruskal Wallis Test

b. Grouping Variable: level of formal education

Source: Author's analysis

When monitoring the value of significance for the recognizability and the quality of facilities and information, it is visible that the significance of the test amounts to less than $5 \%$, that is $\mathrm{p}=0,005$, which indicates that, with the level of reliability of $95 \%$, there is a significant statistical difference for the level of recognizability and the quality of content and information considering the level of formal education of participants, which confirms $\mathrm{H} 1$. 
ToSEE - Tourism in Southern and Eastern Europe, Vol. 5, pp. 233-247, 2019 D. Drpić, D. Vučenović, I. Čapeta: SIGNIFICANCE OF EVENTS IN FORMING A COMPETITIVE ...

Table 4: The satisfaction of participants considering their country of residence ${ }^{\text {a }}$

\begin{tabular}{|c|c|c|c|c|}
\hline & $\begin{array}{c}\text { Recognizability } \\
\text { and quality of } \\
\text { facilities and } \\
\text { information }\end{array}$ & $\begin{array}{c}\text { Infrastructural } \\
\text { facilities }\end{array}$ & $\begin{array}{c}\text { Staff service, } \\
\text { prices and } \\
\text { quality of } \\
\text { additional } \\
\text { facilities }\end{array}$ & $\begin{array}{c}\text { General level of } \\
\text { satisfaction } \\
\text { with the visit }\end{array}$ \\
\hline Mann-Whitney U & 300,000 & 592,000 & 538,000 & 546,000 \\
\hline Wilcoxon W & 1290,000 & 1582,000 & 1528,000 & 1536,000 \\
\hline Z & $-3,850$ &,- 527 & $-1,141$ & $-1,224$ \\
\hline Asymp. Sig. (2-sided) &, 000 &, 598 &, 254 &, 221 \\
\hline
\end{tabular}

a. Grouping Variable: The state of permanent residence

Source: Author's analysis

Observation of the value of significance for the recognizability and the quality of content and information indicates that the significance of the test amounts to less than $5 \%$, that is $\mathrm{p}=0,000$, due to which it can be stated that, with the level of reliability of $95 \%$, there is a significant statistical difference for the level of satisfaction of participants with the recognizability and the quality of content and information considering the country of residence, which confirms $\mathrm{H} 1$.

Table 5: The satisfaction of participants according to the number of visits to the event Špancirfest ${ }^{\mathrm{a}}$

\begin{tabular}{|c|c|c|c|c|}
\hline & $\begin{array}{c}\text { Recognizability } \\
\text { and quality of } \\
\text { facilities and } \\
\text { information }\end{array}$ & $\begin{array}{c}\text { Infrastructural } \\
\text { facilities }\end{array}$ & $\begin{array}{c}\text { Staff service, } \\
\text { prices and } \\
\text { quality of } \\
\text { additional } \\
\text { facilities }\end{array}$ & $\begin{array}{c}\text { General level of } \\
\text { satisfaction } \\
\text { with the visit }\end{array}$ \\
\hline Mann-Whitney U & 405,500 & 646,000 & 551,500 & 546,500 \\
\hline Wilcoxon W & 1225,500 & 1207,000 & 1371,500 & 1366,500 \\
\hline Z & $-2,850$ &,- 158 & $-1,217$ & $-1,484$ \\
\hline Asymp. Sig. (2-sided) &, 004 &, 875 &, 224 &, 138 \\
\hline
\end{tabular}

a. Grouping Variable: How many times have you visited Špancirfest

Source: Author's analysis

If the value of significance for the recognizability and the quality of content and information is observed, it can be concluded that the significance of the test amounts to less than $5 \%$, that is $\mathrm{p}=0,004$, it can be stated that, with the level of reliability of $95 \%$, there is a significant statistical difference for the level of recognizability and the quality of content and information considering the number of visits to Špancirfest, which confirms $\mathrm{H} 1$. 
ToSEE - Tourism in Southern and Eastern Europe, Vol. 5, pp. 233-247, 2019

D. Drpić, D. Vučenović, I. Čapeta: SIGNIFICANCE OF EVENTS IN FORMING A COMPETITIVE ...

Table 6: The satisfaction of participants according to the number of days spent at the destination ${ }^{\mathrm{a}}$

\begin{tabular}{|l|r|r|r|r|}
\hline & $\begin{array}{c}\text { Recognizability } \\
\text { and quality of } \\
\text { facilities and } \\
\text { information }\end{array}$ & $\begin{array}{c}\text { Infrastructural } \\
\text { facilities }\end{array}$ & $\begin{array}{c}\text { Staff service, } \\
\text { prices and } \\
\text { quality of } \\
\text { additional } \\
\text { facilities }\end{array}$ & $\begin{array}{c}\text { General level of } \\
\text { satisfaction } \\
\text { with the visit }\end{array}$ \\
\hline Mann-Whitney U & 558,000 & 611,500 & 506,000 & 584,000 \\
\hline Wilcoxon W & 993,000 & 1046,500 & 941,000 & 1019,000 \\
\hline Z &,- 911 &,- 303 & $-1,506$ &,- 718 \\
\hline Asymp. Sig. (2-sided) &, 362 &, 762 &, 132 &, 473 \\
\hline
\end{tabular}

a. Grouping Variable: Days of stay in a destination

Source: Author's analysis

The data in table 6 indicate that the significance of the test amounts to more than $5 \%$ for all cases $(p>0,05)$, so it can be stated that there is no significant difference between the answers of participants for the categories: recognizability and quality of content and information, infrastructural content, staff services, prices and quality of additional content, general level of satisfaction with the visit considering days of stay at the destination. The following table presents which information sources the respondents used in their decision-making process when deciding to visit Špancirfest.

Table 7: The way of informing the tourists about their choice of the destination Varaždin Špancirfest

\begin{tabular}{|c|c|c|c|}
\hline \multicolumn{2}{|c|}{} & $\mathrm{N}$ & Percentage \\
\hline \multirow{4}{*}{$\begin{array}{c}\text { I found out about } \\
\text { Spancirfest through }\end{array}$} & Internet & 30 & $41,1 \%$ \\
\cline { 2 - 4 } & Newspapers & 1 & $1,4 \%$ \\
\cline { 2 - 4 } & TV & 17 & $23,3 \%$ \\
\cline { 2 - 4 } & Radio & 15 & $0,0 \%$ \\
\cline { 2 - 4 } & Brochures and posters & 0 & $0,0 \%$ \\
\cline { 2 - 4 } & Lecommendation of acquaintances & 10 & $13,7 \%$ \\
\cline { 2 - 4 } & Recommendation of the local & 0 & $0,0 \%$ \\
\cline { 2 - 4 } & population & 0 & $0,0 \%$ \\
\cline { 2 - 4 } & Rest & 73 & $100,0 \%$ \\
\cline { 2 - 4 } & Total & 0 & 0 \\
\hline
\end{tabular}

Source: Author's analysis

The data from the table 7 indicate clearly that the majority of the respondents found out about Špancirfest via Internet (41,1\%), and television $(23,3 \%)$, while 20,5\% saw brochures and posters, which proves $\mathrm{H} 2$. All of the above points to a successfully conducted marketing campaign of management of Špancirfest's activities which actively uses modern technology to promote the event. 
ToSEE - Tourism in Southern and Eastern Europe, Vol. 5, pp. 233-247, 2019

D. Drpić, D. Vučenović, I. Čapeta: SIGNIFICANCE OF EVENTS IN FORMING A COMPETITIVE ...

Table 8: The level of satisfaction of Špancirfest visitors with certain elements of the tourist event

\begin{tabular}{|c|c|c|c|}
\hline $\begin{array}{c}\text { Groups of } \\
\text { characteristics }\end{array}$ & $\begin{array}{c}\text { Elements which influence the } \\
\text { satisfaction with the visit to the tourist } \\
\text { event }\end{array}$ & $\begin{array}{l}\text { Average } \\
\text { grade of the } \\
\text { respondent's } \\
\text { satisfaction }\end{array}$ & SD \\
\hline \multirow{7}{*}{$\begin{array}{l}\text { Recognizability } \\
\text { and quality of } \\
\text { facilities }\end{array}$} & $\begin{array}{l}\text { Recognizability/Image (before the } \\
\text { arrival) }\end{array}$ & 3,90 & 1,16 \\
\hline & Availability of information & 3,52 & 1,07 \\
\hline & Quality of advertising materials & 3,58 & 0,82 \\
\hline & Quality of the organization of the event & 4,04 & 0,68 \\
\hline & Originality of the event & 3,62 & 0,70 \\
\hline & Event being Interesting & 4,00 & 0,62 \\
\hline & $\begin{array}{l}\text { Quality of interpretation of participants } \\
\text { in programs }\end{array}$ & 3,88 & 0,64 \\
\hline \multicolumn{2}{|c|}{ Recognizability and quality of facilities } & 3,79 & 0,20 \\
\hline \multirow{5}{*}{$\begin{array}{l}\text { Infrastructural } \\
\text { facilities }\end{array}$} & Traffic availability & 4,85 & 0,40 \\
\hline & Safety & 4,74 & 0,47 \\
\hline & Tidiness of the attraction's locality & 3,73 & 0,63 \\
\hline & Tidiness of sanitary facilities & 2,59 & 1,36 \\
\hline & Diversity of additional facilities & 2,86 & 0,90 \\
\hline \multicolumn{2}{|r|}{ Infrastructural facilities } & 3,75 & 0,93 \\
\hline \multirow{6}{*}{$\begin{array}{l}\text { Personnel, } \\
\text { prices, facilities }\end{array}$} & $\begin{array}{l}\text { Working hours of hotels and catering } \\
\text { facilities }\end{array}$ & 3,15 & 1,19 \\
\hline & Price of beverages, additional facilities & 3,68 & 0,78 \\
\hline & Souvenirs & 2,74 & 1,07 \\
\hline & Kindness of personnel & 3,67 & 0,65 \\
\hline & $\begin{array}{c}\text { Knowledge and professionalism of } \\
\text { personnel }\end{array}$ & 3,78 & 0,56 \\
\hline & Value for money & 3,86 & 0,71 \\
\hline \multicolumn{2}{|r|}{ Personnel, prices, facilities } & 3,55 & 0,40 \\
\hline \multicolumn{2}{|c|}{ General level of satisfaction with the visit } & 3,60 & 0,49 \\
\hline
\end{tabular}

Source: Author's analysis

The participants have shown a high level of satisfaction with recognizability of the event and the availability of information about the event. The highest value of the arithmetic mean of participants' responses was determined for the questions: the quality of the event's organization where the arithmetic mean is 4,04 while the standard deviation is 0,62 . The lowest value of the arithmetic mean of the participants' responses is recorded for the question: the availability of information, where the arithmetic mean is 3,52, with the standard deviation of 1,07 . The participants have shown a very high level of satisfaction with the infrastructural facilities of Špancirfest and the city of Varaždin, which was marked very good $(3,75)$. There the highest value of the arithmetic mean of visitors corresponds with traffic availability $(4,85)$, with the standard deviation of 0,40 , also security $(4,74)$ with the standard deviation of 0,47 . The lowest value of arithmetic means of visitor's responses is shown in consideration of the cleanliness of sanitary facilities $(2,59)$, with the standard deviation of 1,36. A lower level of satisfaction was also recorded by visitors for the variety of additional facilities $(2,86)$. The highest value 
ToSEE - Tourism in Southern and Eastern Europe, Vol. 5, pp. 233-247, 2019

D. Drpić, D. Vučenović, I. Čapeta: SIGNIFICANCE OF EVENTS IN FORMING A COMPETITIVE ...

of arithmetic means of visitors' responses is recorded for the question: value for money $(3,86)$, with the standard deviation of 0,71 which means that the visitors are satisfied with the service and the program with correlation to the money spent, but it should be noted that the entrance to the festival is free, which can affect the level of satisfaction. The lowest value of the arithmetic means of visitors' responses is recorded for the question: working hours of hotels and catering facilities $(3,15)$, with the standard deviation of 1,19 which points to the fact that the management of the destination and the city of Varaždin should take in consideration a possibility to prolong the working hours of hotels and catering facilities. A lower grade was awarded to the offer of autochthonous souvenirs $(2,74)$, which points to the need for creating and making an autochthonous souvenir of Varaždin and Špancirfest. The knowledge and the staff professionalism $(3,78)$, as well as their amiability $(3,67)$ were marked very satisfactory. If the general level of satisfaction with the visit is considered, it can be noticed that the arithmetic mean is 3,60 , with the standard deviation of 0,49 . So it can be concluded that the visitors are very satisfied with their visit to Špancirfest, which confirms H3.

\section{THE INTEGRAL PRODUCT OF THE CITY OF VARAŽDIN - VARAŽDIN THE FLOWER OF NORTHERN CROATIA}

An analysis was formed based on the previously shown data of all the advantages and disadvantages of Špancirfest according to the opinions of research participants. In addition, possible guidelines will be determined for future development as well as possible threats that can have a negative impact on the position of the tourist event on the market. S.W.O.T. analysis will be used to ascertain the competitive position of Špancirfest, the representative of contemporary urban culture of the city of Varaždin.

The basic advantage of the event is its easy accessibility and adaptability to all generations, as well as the diversity of program elements. Developmental opportunities are varied, and they are based on establishing the cross-border cooperation, strengthening of knowledge, and skills in management, following market trends, and the possibilities of financing the event. Developmental risks are connected with the possibility of environmental pollution, loss of sponsorship, and threats to the loss of security. A proposal was made, based on the S.W.O.T. analysis, of an integral product of the city of Varaždin, which uses Špancirfest as its starting point, and it was upgraded with all the elements of the offer in the city of Varaždin. 
ToSEE - Tourism in Southern and Eastern Europe, Vol. 5, pp. 233-247, 2019

D. Drpić, D. Vučenović, I. Čapeta: SIGNIFICANCE OF EVENTS IN FORMING A COMPETITIVE ...

Picture 1: The integral tourist product of the city of Varaždin-VaraždinThe flower of Northern Croatia

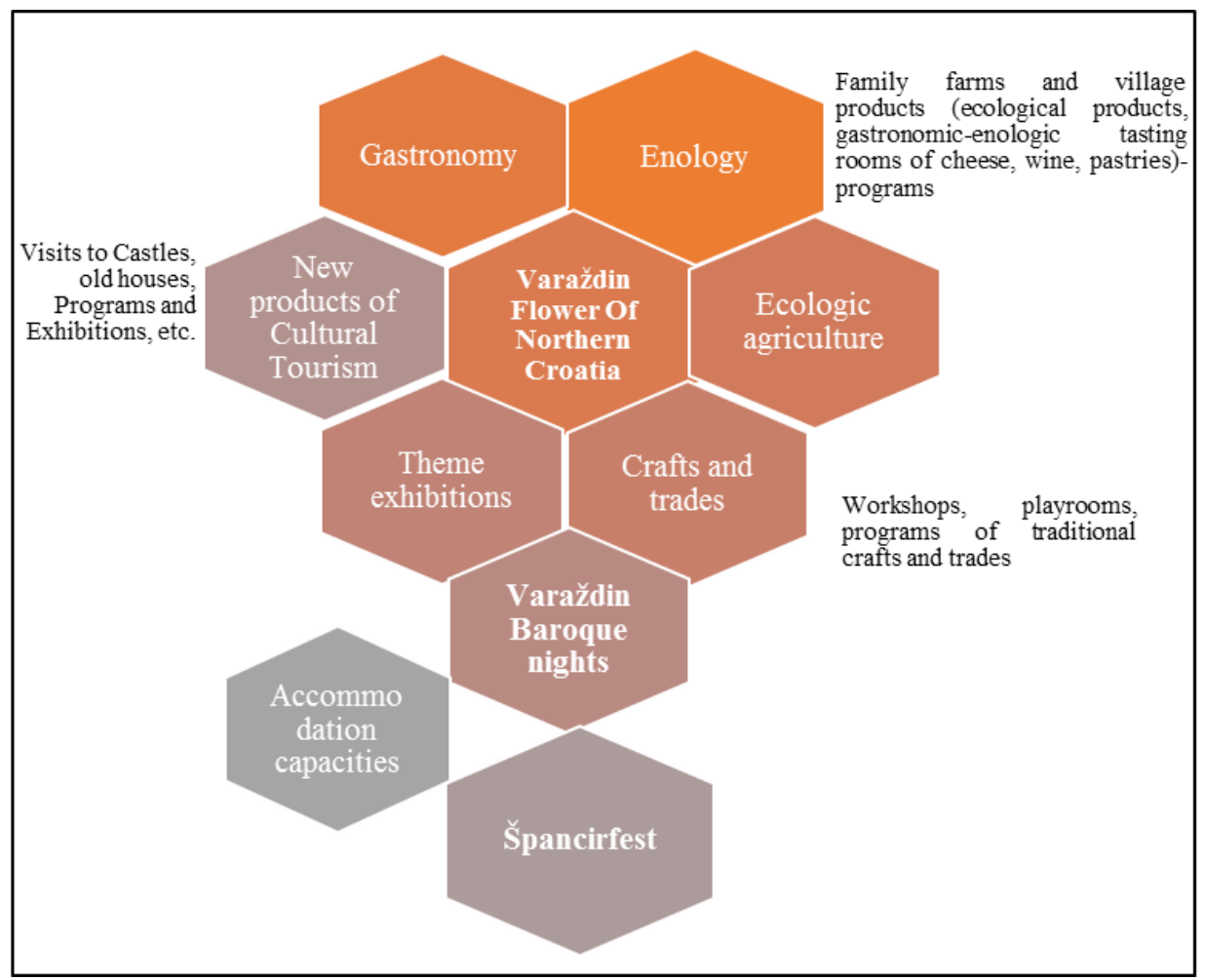

Source: Author's analysis

Improving the competitive position of the city of Varaždin on the tourist market, including Špancirfest, is possible with an upgrade of the already existing products of the tourist destination Varaždin. Špancirfest is conceived as a basic product of a new set of tourist products under the same name Varaždin-the flower of northern Croatia. Elements of the flower can be regularly changed, complemented with new petals or removed from the set of products. The goal of the flower of products is to create a product, based on the most visited events in Varaždin, which will encourage all visitors to visit Varaždin again even besides the main program of Špancirfest. Because of that the program of Špancirfest should include all the products that make the flower, in order to use the exceptional promotional-educational potential of Špancirfest. In addition, Špancirfest would be a part of every element of the flower, making the connection with the city, the visitors, and the local community, making the connection and the strengthening of the identity of Varaždin on the market. The product and the tourist programs would include elements of gastro-enological offer of northern Croatia, manufactured at family farms from the area by using high ecological standards of manufacture, market placement, and offer. During the years, all of the exhibitions and programs that are being held at the city galleries, castles, and streets, would include a unique marketing message for that year, which would enable to create a richer and diversified offer of Špancirfest as the main 
ToSEE - Tourism in Southern and Eastern Europe, Vol. 5, pp. 233-247, 2019

D. Drpić, D. Vučenović, I. Čapeta: SIGNIFICANCE OF EVENTS IN FORMING A COMPETITIVE ...

element of the flower. Cultural heritage, traditional handicraft and trade, and elements of non-material heritage (songs, dances) would be actively included in all elements of the program.

The goals of the tourist product-marketing brand of Varaždin-the flower of Northern Croatia are:

- $\quad$ Removal of determined disadvantages of the existing tourist offer;

- Improvement of marketing and promotional activities by a common approach (more affordable promotional packages);

- Inclusion of traditional products from family farms of the Varaždin County;

- Tourist valorization of material heritage based on sustainability;

- Tourist valorization of non-material heritage, and prevention from it falling into oblivion and disappearing;

- $\quad$ Rich enological offer becoming an integral part of the whole product;

- Simpler approach to the market for all stakeholders on the tourist market of the destination;

- Stronger identity of the destination and a sense of belonging between the local community and the visitors;

- Continuous incentive towards innovation and improvement of the offer;

- Possibility of introducing domestic and international standards of quality.

The implementation of stated goals would achieve a stronger recognizability and economic success of the set of tourist products for the city of Varaždin on the tourist market. The local community will be included in all elements of planning the products which grows their acceptance of tourism as an important socio-economic branch, and puts an end to misunderstandings between the local community, and the visitors of the destination. The approach of the flower enables active and permanent inclusion of the local food and drinks manufacturers into the supply chain, which secures their sustainable development, and growth of economic performances of all components of the integrated product of Varaždin-the flower of northern Croatia.

\section{CONCLUSION}

Based on the results of the empirical research, the authors tried to point out the importance of tracking the socio-economic characteristics of visitors of the tourist event Špancirfest in order to clearly appoint the levels of their satisfaction with the existing offer, and determine the means and steps with a goal of removing possible deficiencies. The conducted research has proven the set hypothesis within the paper, and can be concluded that the visitors of Špancirfest are very satisfied with the existing offer, and they get information about it mostly by using information technology, usually web sites. This paper's suggested integral tourist product of the city of Varaždin-Varaždin-the flower of Northern Croatia has a goal to facilitate the management of the existing product Špancirfest, and to execute its upgrade with a set of other more or less known tourist events of the city of Varaždin and other destinations of Northern Croatia. The above stated strives to achieve added value, and increase in quality of the tourist offer, which would, it can be assumed, positively affect the competitive position of the tourist destination Varaždin and its surrounding. In addition 
ToSEE - Tourism in Southern and Eastern Europe, Vol. 5, pp. 233-247, 2019

D. Drpić, D. Vučenović, I. Čapeta: SIGNIFICANCE OF EVENTS IN FORMING A COMPETITIVE ...

to the positive implications on the development of tourist economy, the stated will positively affect the entire quality of life of the local community, strengthening of the identity and pride of all stakeholders of the destination in creating a sense of connection with the visitors of Špancirfest as the main product of the destination. A relatively small number of research participants can be mentioned as a limitation of the conducted research, but it is still significant and represents the basis to determine guidelines for further improvement of the tourist product Špancirfest. The precision of the research would be improved by the organizers' more precise keeping of statistical tracking of number of visitors, since it is now only based on estimation. The authors therefore suggest implementation of possible on-line or application based registration of visitors before they come to the event, or at the info desk before they attend the attractions and the program. As limitations of the research, it is necessary to emphasize the sample size due to the limited funds of the authors and time limit. Despite the fact that it can be characterized as a lack, it is the author's opinion that based on the findings it is possible to form guidelines for further development of the offer and growth of the visitor's satisfaction. The research should be repeated in a reasonable period of time on a bigger statistical sample.

\section{REFERENCES}

Cooper, C. (1998), Tourism: Principles and practice, Pearson Education, United Kingdom.

Čorak, S. and Trezner, Ž. (2014), Destinacijske menadžment kompanije, Priručnik za uspješno poslovanje $i$ marketing u turizmu posebnih interesa, Hrvatska turistička zajednica Zagreb, Republika Hrvatska.

David, L. (2009), “Environmental Impacts of Events”, Razaq, R. and Musgrave, J. (Ed.), Event Management and Sustainability, CAB International, Wallingford, pp. 66-75

Deery, M. and Jago, L. (2010), "Social impacts of events and the role of anti-social behavior", International Journal of Event and Festival Management, Vol. 1, No. 1, pp. 8-28 https://doi.org/10.1108/17852951011029289

Destination British Columbia (2007), Guidelines: Survey procedures for Tourism Economic Impact Assessments of Gated Events and Festivals, Festivals \& Cultural Events Initiative-Research Guidence \& Template, viewed 02 January 2019 https://www.destinationbc.ca/content/uploads/2018/08/Gated_Events_Festivals-economicimpact.pdf

Drpić, D. (2017), Turistički događaji temeljeni na baštini i konkurentnost turističke ponude, doktorska disertacija [Tourist Events based on heritage and competitiveness of tourist offer, Doctoral Dissertation], Opatija, Faculty of Tourism and Hospitality Management Opatija, Republic of Croatia.

Flightnetwork (2018), Europes top 20 art and culture festivals in 2018, viewed 01 January 2019 , https://www.flightnetwork.com/blog/europes-top-20-art-and-culture-festivals-in2018/\#\%C5\%A0pancirfest

Getz, D. (2005), Event Management \& Event Tourism, Cognizant Communication Corporation, New York

Getz, D. (2010), Event management \& Event Tourism, Cognizant Communication Corporation, New York.

Getz, D. (2008), "Event tourism: Definition,evolution, and research", Tourism Management, Vol. 29, pp. 403428 https://doi.org/10.1016/j.tourman.2007.07.017

Government of the Republic of Croatia (2013), Strategy of Development of Tourism of the Republic of Croatia until year 2020, viewed 01 January 2019, https://mint.gov.hr/UserDocsImages/arhiva/130426Strategija-turizam-2020.pdf

Gračan D. and Rudančić-Lugarić, A. (2013), "Konkurentnost turističke destinacije - studija slučaja (case study) Riječki karneval" [Tourism Destination Competitiveness: Rijeka Carnival Case Study], Ekonomski vjesnik: Review of Contemporary Entrepreneurship, Business, and Economic Issues, Vol. 26, No. 1, pp. 271-282

Griffin, T. and Hayllar, B. (2009), "Urban tourism Precincts and the Experience of Place", Journal of hospitality marketing \& management, Vol. 18, No. 2-3, pp. 127-153, https://doi.org/10.1080/19368620802590167 
ToSEE - Tourism in Southern and Eastern Europe, Vol. 5, pp. 233-247, 2019

D. Drpić, D. Vučenović, I. Čapeta: SIGNIFICANCE OF EVENTS IN FORMING A COMPETITIVE ...

Gržinić, J. (2018), Turizam i razvoj - rasprava o globalnim izazovima [Tourism and Development-Discussion about Global Challenges], University of Juraj Dobrila in Pula, Republic of Croatia.

Hall, M. (1997), "Mega-events and their legacies", in. Murphy, U.P. (Ed.), Quality Management in Urban Tourism, Wiley, Chichester, pp. 75-87.

Henderson, S. (2011), "The development of competitive advantage through sustainable event management", Worldwide Hospitality and Tourism Themes, Vol. 3, No. 3, pp. 245-257, https://doi.org/10.1108/17554211111142202

Institute for Tourism (2008), TOMAS stavovi i potrošnja posjetitelja kulturnih atrakcija $i$ događanja $u$ Hrvatskoj [TOMAS Attitudes and Consumption of visitors of Cultural Attractions and Events in Croatia], viewed 01 January 2019, http://www.iztzg.hr/UserFiles/File/novosti/2009_TOMAS_Kulturni_turizam_2008_Sazetak_i_Pre zentacija.pdf

Ivančić, I. (2015), Međuovisnost turističkih događaja u okruženju i uspješnost hotelijerstva, doktorska disertacija [Interdependence between surrounding tourist events and the success of hospitality service, Doctoral Dissertation] Faculty of Tourism and Hospitality Management Opatija, Republic of Croatia.

Janeczko, B., Mules, T. and Ritchie, B. (Eds.). (2002), Estimating the Economic Impacts of Festivals and Events: a research guide, viewed 02 January 2019, https://lccn.loc.gov/2002489334

Kušen, E. (2002), Turistička atrakcijska osnova [Tourist Attraction Resource], Institute of Tourism Zagreb, Zagreb.

Magaš, D., Vodeb, K., Zadel, Z. (2018), Management turističke organizacije i destinacije [Management of a Tourist Destination and Organization], Faculty of Tourism and Hospitality Management Opatija Republic of Croatia.

McHone, W.W. and Rungeling, B. (2000), "Practical issues in measuring the impact of a cultural tourist event in a major tourist destination", Journal of Travel Research, Vol. 38, No. 3, pp. 300-303, https://doi.org/10.1177\%2F004728750003800313

Milohnić, I. and Trošt, K. (2011), "Management of sustainable and responsible event practices in tourism (Case study: Ulysses Theatre)". In Proceedings of Entrepreneurship and Macroeconomic Management: Reflections on the World in Turmoil, March 24-26, 2011, pp. 1733-1750, Pula, Republic of Croatia.

Musgrave, J. (2011), "Moving towards responsible events management", Worldwide Hospitality and Tourism Themes, Vol. 3, No. 3, pp. 258-274, https://doi.org/10.1108/17554211111142211

Ontario Ministry of Tourism, Culture and Sport, (2007), Guidelines: Survey Procedures for Tourism Economic Impact Assessments of Gated Events and Festivals, Research Resolutions \& Consulting Ltd, viewed 01 January 2019,

http://www.mtc.gov.on.ca/en/research/resources/Guidelines_Econ_Impact_Gated_Events_2007.p df, ISBN 978-1-4249-7634-8 PDF

Pirjavec, B., Kesar, O. (2002), Počela turizma [Tourism Principles], Mikrorad and Faculty of Economics in Zagreb, Zagreb, Republic of Croatia.

Presbury, R and Edwards, D.C. (2010), "Managing sustainable festivals, meetings and events", in Liburd, J. and Edwards, J. (Ed.), Understanding the Sustainable Development of Tourism, Goodfellow Publishers Limited, Abingdon, United Kingdom, pp. 163-187.

Swarbrooke, J. (1999), Sustainable Tourism Management, CABI Publishing, Oxfordshire.

Tassiopoulos, D. and Johnson, D. (2009), "Social impacts of events”, in Raj, R., Musgrave, J. (Eds.), Event Management and Sustainability, CAB International, Wallingford, pp. 76-89.

The Offical Website of Špancirfest (2018), viewed 01 January 2019, https://spancirfest.com/

Tomljenović, R., Marušić, Z., (2019), "Evaluacija kulturnih i sportskih događanja - primjer Vodiča za evaluaciju događanja" [Evaluation of Cultural and Sports Events-Example of the Guide for Event Evaluation], in Marušić, M, Prebežac, D. and Mikulić, J. (Eds.), Istraživanje turističkih tržišta [Tourist Market Research], Faculty of Economics in Zagreb, Zagreb, pp. 331-340.

University of Liverpool (2008), Estimating the Economic Benefits of Event Tourism A Review of Research Methodologies, viewed 03 January 2019, https://www.liverpool.ac.uk/media/livacuk/impacts08/pdf/pdf/Impacts08 HBond_Oct_2008_Econ_Benefits_of_Event_Tourism.pdf

Weaver, D.B. (2006), Sustainable Tourism: Theory and Practice, Elsevier Butterworth-Heinemann, Amsterdam, Holland.

Wood, E.H. (2005), "Measuring the economic and social impacts of local authority events", International Journal of Public Sector Management, Vol. 18, No. 1, pp. 37-53, doi 10.1108/09513550510576143 
ToSEE - Tourism in Southern and Eastern Europe, Vol. 5, pp. 233-247, 2019

D. Drpić, D. Vučenović, I. Čapeta: SIGNIFICANCE OF EVENTS IN FORMING A COMPETITIVE ...

Danijel Drpić, $\mathrm{PhD}$, Assistant

Polytechnic University in Rijeka

Vukovarska 58 Street, Rijeka, Croatia

Phone: +385 51 353-752

E-mail: danijel_drpic@hotmail.com

Danijel Vučenović, $\mathrm{PhD}$

Ministry of Interior

The Street of the City of Vukovar

E-mail: danijel.vucenovic@gmail.com

Ivan Čapeta, PhD Student

University of Rijeka

Faculty of Tourism and Hospitality Management

Primorska 42, 51410 Opatija, Croatia

E-mail: vici.doo@gmail.com 